\title{
Starvation of the Respiratory Metabolism and Locomotion of Aurelia aurita s.l. Ephyrae
}

\author{
Zhilu Fu' ${ }^{*}$, Shin-Ichi Uye ${ }^{2}$ \\ ${ }^{1}$ Key Laboratory of Protection and Utilization of Marine Resources, Guangxi University for Nationalities, Nanning, China \\ ${ }^{2}$ Graduate School of Biosphere Science, Hiroshima University, Higashi-Hiroshima, Japan \\ Email: ‘fzl19@163.com, suye@hiroshima-u.ac.jp
}

How to cite this paper: $\mathrm{Fu}, \mathrm{Z}$. and Uye, S.-I. (2021) Starvation of the Respiratory Metabolism and Locomotion of Aurelia aurita s.l. Ephyrae. Open Journal of Marine Science, 11, 1-16.

https://doi.org/10.4236/ojms.2021.111001

Received: October 7, 2020

Accepted: November 27, 2020

Published: November 30, 2020

Copyright $\odot 2021$ by author(s) and Scientific Research Publishing Inc. This work is licensed under the Creative Commons Attribution International License (CC BY 4.0).

http://creativecommons.org/licenses/by/4.0/

(c) (i) Open Access

\begin{abstract}
Blooms of the scyphozoan jellyfish Aurelia aurita are greatly regulated by the survival rate of planktonic ephyrae. The ecophysiology of ephyrae is poorly studied compared with polyps and medusae. As extremely strong starvation resistance and recovery capability of $A$. aurita ephyrae may due to its low metabolic rate as well as starvation may reduce the swimming ability of ephyrae which may lead to the higher predation loss, the effects of temperature and starvation on their respiration and pulsation rates were examined. In this study, ephyrae under different starvation conditions were measured by a fluorescence-based DO meter after $72 \mathrm{~h}$ incubation. And the pulsation rates were measured at every 10 -d interval in 1-liter plastic bottle by a hand-held counter. The results showed that the mean respiration rates of newly released ephyrae were $0.24,0.24$ and $0.19 \mu \mathrm{l} \mathrm{O}_{2}$ ephyra $^{-1} \mathrm{~d}^{-1}$ at $15^{\circ} \mathrm{C}, 12^{\circ} \mathrm{C}$ and $9^{\circ} \mathrm{C}$, respectively, and the rates tended to decrease with increasing starvation duration. Carbon weight-specific respiration rates did not change significantly with starvation duration. The dry weight-specific respiration rates of newly released $A$. aurita ephyrae (i.e., $11.7-14.6 \mu \mathrm{l} \mathrm{O}_{2} \mathrm{mg} \mathrm{DW}^{-1} \mathrm{~d}^{-1}$ ) were nearly one order of magnitude lower than the rates for planktonic larvae of other taxa (e.g., molluscs, crustaceans and fish). The maximum pulsation rate taken by $A$. aurita ephyrae was 49.2 beats $\mathrm{min}^{-1}$, which represents the maximum swimming velocity to be $8.87 \mathrm{~cm} \cdot \mathrm{min}^{-1}$. The pulsation rates were not affected by temperature over the range between $9^{\circ} \mathrm{C}$ and $15^{\circ} \mathrm{C}$. However, they were influenced by starvation duration. Starvation-derived decrease in pulsation together with associated body shrinkage may lead to lower encounter rate of prey and lower escaping ability from predators, which may lead to higher predation loss in the field.
\end{abstract}

\section{Keywords}

Aurelia aurita, Ephyrae, Starvation, Respiration, Pulsation 


\section{Introduction}

The moon jellyfish Aurelia aurita s.l. is the most common scyphozoan jellyfish in coastal waters around the world, and mass occurrences of this species have been reported from various regions. In recent decades, $A$. aurita blooms have become increasingly prominent in East Asian seas, causing serious problems to human sectors such as fisheries and coastal power plant operations [1] [2] [3] [4]. In addition, $A$. aurita can also have negative impacts on the marine food chain because it is a food competitor and predator of fish eggs and larvae [5] [6]. If jellyfish become more prevalent, fishery resources will be reduced [3] [7] [8]. Therefore, it is important to identify causes for the enhancement of A. aurita populations to forecast likely outbreaks prior to the season of medusa blooms.

In the life cycle of $A$. aurita, planktonic ephyrae play a critical role in population recruitment since the mortality of ephyrae can significantly influence the subsequent population of medusae [9] [10]. However, studies on this vulnerable stage have seldom been reported. Similar to that of other marine larvae, the survivorship of ephyrae mainly depends on two major factors: 1) starvation and 2) predation. Our previous study found that $A$. aurita ephyrae have extremely strong starvation resistance and recovery capability, which are indicated by their extraordinarily long $P N R_{50}$ (i.e., duration of starvation at which $50 \%$ of ephyrae could recover from starvation and grow to the next stage) [9]. The $P N R_{50}$ of $A$. aurita ephyrae was measured to be $33.8 \mathrm{~d}, 38.4 \mathrm{~d}$ and $58.6 \mathrm{~d}$ at $15^{\circ} \mathrm{C}, 12^{\circ} \mathrm{C}$ and $9^{\circ} \mathrm{C}$, respectively [9]. However, the mechanisms that lead to this extremely strong starvation resistance and recovery capability are not yet understood. Our previous study has found that the reduction rates of body carbon contents of ephyrae with prolonged starvation were very slow [9]. Therefore, we consider that such starvation resistance and recovery capability may be attributed to extremely low metabolic rates of starved ephyrae.

Although $A$. aurita ephyrae have extraordinarily strong starvation resistance and recovery capability, starvation caused the morphological damages may reduce their swimming ability which is closely associated with feeding and escaping capabilities. The reduction of swimming ability would reduce prey encounter rate, prey capture success and ability of avoidance from predators, which may cause higher predation loss in the field.

In recent decades, the respiration rates of jellyfish, particularly $A$. aurita, have been extensively studied [11]-[20]. However, the measurements were confined to the medusa and polyp stages, and respiration rates of ephyrae have seldom been measured [21]. Several studies have researched the pulsation rate of $\mathrm{A}$. aurita [22] [23] [24]. However, among these studies, only Algueró-Muñiz et al. [25], Mangum et al. [26] and Dillon [27] have studied the pulsation rate for ephyrae. All of these studies showed that the pulsation rate was strongly influenced by temperature. Starvation on the respiration and pulsation of ephyrae has never been reported.

Objective of this study has two folds: 1) to test whether the lower metabolic rates of $A$. aurita ephyrae under starvation is the main reason for the extremely 
long $P N R_{50}$ of $A$. aurita ephyrae; 2) to test whether starvation can reduce the swimming ability, which may lead to the high predation loss in the field. To test these hypotheses, we measured the actual respiration and pulsation rates of $A$. aurita ephyrae at 3 different temperatures from $9^{\circ} \mathrm{C}-15^{\circ} \mathrm{C}$ under different starvation durations.

\section{Materials and Methods}

\subsection{Origin and Maintenance of Polyps}

Ephyrae of $A$. aurita were obtained from stock cultures of polyps derived from matured medusae in the Inland Sea of Japan. Planulae of $A$. aurita were collected from the oral arms of matured medusae and placed in plastic containers (diameter: $15 \mathrm{~cm}$, depth: $6.5 \mathrm{~cm})$ containing ca. 11 of filtered $(0.2 \mu \mathrm{m})$ seawater of salinity 32 . These planulae were incubated at $25^{\circ} \mathrm{C}$ in darkness to allow them to settle on the walls of containers. After transformation to polyps, they were fed ad libitum with newly hatched Artemia sp. nauplii once or twice weekly, followed by replacement of the seawater. These polyps were maintained as stock cultures.

\subsection{Respiration Measurements}

The stock-cultured $A$. aurita polyps maintained at ca. $25^{\circ} \mathrm{C}$ were transferred to $13^{\circ} \mathrm{C}$ to induce strobilation and release of ephyrae. Newly released ephyrae were kept starved in plastic containers containing ca. 11 of filtered seawater (salinity: 32) and were maintained at three different temperatures (i.e., $9^{\circ} \mathrm{C}, 12^{\circ} \mathrm{C}$ and $15^{\circ} \mathrm{C}$ ) in darkness for various periods, ranging from 0 to $60 \mathrm{~d}$, prior to respiration measurement experiments. These three temperatures (i.e., $9^{\circ} \mathrm{C}, 12^{\circ} \mathrm{C}$ and $15^{\circ} \mathrm{C}$ ) represent the lowest, medium and highest temperatures in the winter in the Inland Sea of Japan. The aerated filtered seawater used in the respiration experiments was produced by air stone aeration for ca. $1 \mathrm{~h}$. In each experiment, 20 to 50 ephyrae were pipetted into a small vial (ca. $10 \mathrm{ml}$ volume) in which seawater was completely replaced with aerated seawater and then transferred into a dissolved oxygen (DO) bottle $(60.0 \mathrm{ml}$ volume) containing the same aerated seawater. Three bottles were prepared for either respiration measurement or to serve as a control, and they were placed in dark incubators for $72 \mathrm{~h}$ with periodical ( $4-8 \mathrm{~h}$ intervals) inversions of the bottles by hand. The selection of numbers of ephyrae (20 - 50) and incubation duration (72 h) was performed based on preliminary determination of the respiration rate of an ephyra so that the consumption of DO would be larger than the precision level $\left(0.02 \mathrm{mg} \mathrm{O}_{2} \mathrm{l}^{-1}\right)$ of a fluorescence-based DO meter (WTW, Multi 3410 with FDO 925 probe). The DO before and after the experiment was measured, and the ephyrae used in the experiment were observed under a stereomicroscope to check their survival. At least 10 of them were photographed by a digital camera to measure their size.

\subsection{Pulsation Rates}

Total of 60 newly released $A$. aurita ephyrae originating from stock-cultured po- 
lyps were prepared, and they were individually placed in wells of 6-well polystyrene culture plates containing $10 \mathrm{ml}$ of filtered seawater of salinity 32. Each lot consisting of 20 ephyrae was transferred to three temperatures $\left(\right.$ i.e. $9^{\circ} \mathrm{C}, 12^{\circ} \mathrm{C}$ and $15^{\circ} \mathrm{C}$ ), and kept starved for up to $60 \mathrm{~d}$. The seawater in the wells was replaced twice weekly. Newly released ephyrae at each temperature were photographed under a stereomicroscope to measure their size, and used for the experiment to measure their pulsation rates. Pulsation rate of each ephyra was measured at every 10-day interval.

For the pulsation determination, an ephyra was transferred to a 1-liter plastic bottle filled with seawater of respective temperature, and then its pulsations were counted with a hand-held counter for one min for three successive min. The experiment was conducted under dim light. The mean pulsation rate was determined from 3 counts for each of specimens.

\subsection{Statistical Analysis}

The respiration rates and pulsation rates in different treatments were analyzed by one-way or two-way ANOVA (SPSS 26.0 software). If the overall ANOVA results were significant $(\mathrm{P}<0.05)$, the means were compared using Tukey's pairwise comparison.

\section{Results}

\subsection{Effects of Starvation and Temperature on Respiration Rates}

As described in Fu et al. [9], the size and morphology of ephyrae changed with prolonged duration of starvation, and these changes were more rapid in higher temperature treatments.

The mean $( \pm S D)$ respiration rates of newly released ephyrae were $0.24 \pm 0.07$, $0.24 \pm 0.03$ and $0.19 \pm 0.06 \mu \mathrm{O}_{2}$ ephyra $^{-1} \mathrm{~d}^{-1}$ at $15^{\circ} \mathrm{C}, 12^{\circ} \mathrm{C}$ and $9^{\circ} \mathrm{C}$, respectively (Figure 1), although there was no significant difference between them (one-way



Figure 1. The mean respiration rate of an Aurelia aurita ephyra kept starved for various periods at $9^{\circ} \mathrm{C}, 12^{\circ} \mathrm{C}$ and $15^{\circ} \mathrm{C}$. Error bars: SD. Filled triangles: $P N R_{50}$ at $15^{\circ} \mathrm{C}(33.8 \mathrm{~d})$, $12^{\circ} \mathrm{C}(38.4 \mathrm{~d})$ and $9^{\circ} \mathrm{C}(58.6 \mathrm{~d})$ from left to right. 
ANOVA, $\mathrm{P}>0.05)$. The respiration rates showed a general trend of decreasing with increasing starvation duration; in the beginning, the decrease was relatively smooth and small, but after 30 to $40 \mathrm{~d}$ of starvation, it appeared to be rapid. The rate decreased nearly to or below half of the rate shown by non-starved ephyrae when the starvation was longer than $P N R_{50}$ (Figure 1). However, the statistical tests failed to show any significant difference in the respiration rates as a function of temperature (two-way ANOVA, $\mathrm{P}>0.05$ ), duration of starvation (two-way ANOVA, $\mathrm{P}>0.05$ ) or their interactions (two-way ANOVA, $\mathrm{P}>0.05$ ) during the first $30 \mathrm{~d}$ of starvation. Meanwhile, the respiration rate on Day 0 was significantly higher than the respiration rate on Day 30 (Tukey's pairwise comparison, $\mathrm{P}<0.05)$. At $9^{\circ} \mathrm{C}$ and $12^{\circ} \mathrm{C}$, there was no significant difference in the respiration rates for different durations of starvation (one-way ANOVA, $\mathrm{P}>0.05$ ). However, at $15^{\circ} \mathrm{C}$, the duration of starvation did significantly affect the respiration rate between Day 0 and Day 40 (one-way ANOVA, P < 0.05).

The carbon weight-specific respiration rates were calculated by dividing individual respiration rates by individual carbon weights. The carbon weight of $A$. aurita ephyrae was already reported in a previous study of ours [9]. The mean ( \pm $\mathrm{SD})$ carbon weight-specific respiration rates of newly released ephyrae were $35.6 \pm 10.3,37.9 \pm 4.2$ and $29.4 \pm 9.4 \mu \mathrm{O}_{2} \mathrm{mg} \mathrm{C}^{-1} \mathrm{~d}^{-1}$ at $15^{\circ} \mathrm{C}, 12^{\circ} \mathrm{C}$ and $9^{\circ} \mathrm{C}$, respectively (Figure 2), without a significant difference between temperatures (one-way ANOVA, $\mathrm{P}>0.05$ ). The specific respiration rates were almost constant over the starvation period up to $40 \mathrm{~d}$ (Figure 2), as a statistical test did not show a significant difference in the rates with temperature (two-way ANOVA, $\mathrm{P}>0.05$ ), duration of starvation (two-way ANOVA, $\mathrm{P}>0.05$ ) or their interactions (two-way ANOVA, $\mathrm{P}>0.05$ ). Moreover, at each temperature, one-way ANOVA failed to detect any significant difference in the rates with duration of starvation $(\mathrm{P}>0.05)$.

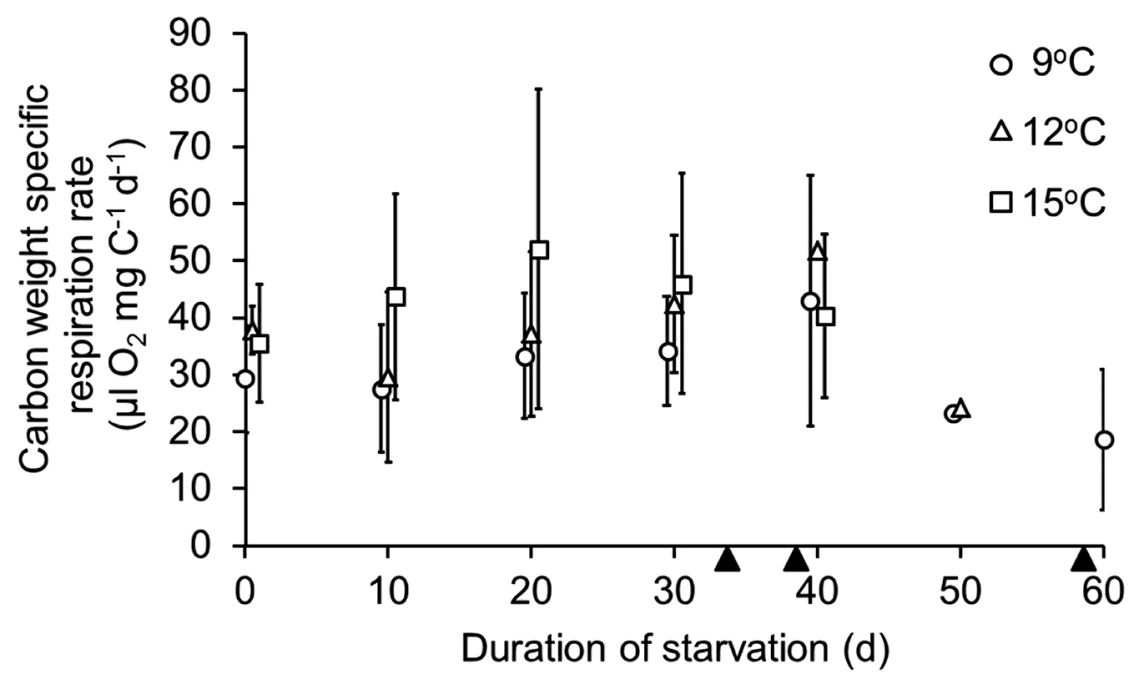

Figure 2. The mean carbon weight-specific respiration rate of an Aurelia aurita ephyra kept starved for various periods at $9^{\circ} \mathrm{C}, 12^{\circ} \mathrm{C}$ and $15^{\circ} \mathrm{C}$. Error bars: SD. Filled triangles: $P N R_{50}$ at $15^{\circ} \mathrm{C}(33.8 \mathrm{~d}), 12^{\circ} \mathrm{C}(38.4 \mathrm{~d})$ and $9^{\circ} \mathrm{C}(58.6 \mathrm{~d})$ from left to right. 


\subsection{Effects of Starvation and Temperature on Pulsation Rates}

The mean $( \pm \mathrm{SD})$ disc diameter of newly released ephyrae used in this experiment was $2.19 \pm 0.18 \mathrm{~mm}$. Twenty ephyrae died during the experiment due perhaps to the mechanical damage with pipetting. At the end of the experiment, there were 16,15 and 15 ephyrae remaining at $9^{\circ} \mathrm{C}, 12^{\circ} \mathrm{C}$ and $15^{\circ} \mathrm{C}$, respectively, and they all looked active.

The mean $( \pm \mathrm{SD})$ pulsation rate of newly released ephyrae was $18.8 \pm 6.3,20.3$ \pm 11.2 and $28.2 \pm 13.8$ beats ephyra ${ }^{-1} \mathrm{~min}^{-1}$ at $9^{\circ} \mathrm{C}, 12^{\circ} \mathrm{C}$ and $15^{\circ} \mathrm{C}$, respectively (Figure 3), with significant difference with temperature (one-way ANOVA, $\mathrm{P}<$ 0.05). Over the starvation period up to 50 days, two-way ANOVA showed a significant effect of starvation on pulsation rate $(\mathrm{P}<0.01)$, but did not show any significant effect of temperature $(\mathrm{P}>0.05)$ and their interactions $(\mathrm{P}>0.05)$. Tukey's test showed that the pulsation rate on Day 0 was significantly lower than that on Day 10, Day 20 and Day $30(\mathrm{P}<0.01)$, the same test also showed that the rate on Day 20 was significantly higher than that on Day 0, Day 40 and Day 50 $(\mathrm{P}<0.01)$.

\section{Discussion}

\subsection{Effects of Starvation and Temperature on Respiration Rates}

Our study is the first study to measure respiration for newly released $A$. aurita ephyrae (mean disc diameter (DD): $2.02 \pm 0.19 \mathrm{~mm}$ ). Previous work had measured the respiration for slightly advanced ephyra stages whose DD values were $4.2 \mathrm{~mm}$ [11] and $5.1 \mathrm{~mm}$ [14]. The respiration rates at $15^{\circ} \mathrm{C}$ were calculated to be $0.42 \mu \mathrm{l} \mathrm{O}_{2}$ ephyra $^{-1} \mathrm{~d}^{-1}$ [14] and $0.74 \mu \mathrm{O}_{2}$ ephyra $^{-1} \mathrm{~d}^{-1}$ [11]. Compared to these rates, the respiration rate measured at $15^{\circ} \mathrm{C}$ in this experiment (i.e., $0.24 \mu \mathrm{l}$ $\mathrm{O}_{2}$ ephyra $^{-1} \mathrm{~d}^{-1}$ ) was significantly lower.



Figure 3. The mean pulsation rate (contractions of umbrella per minute) of an Aurelia aurita ephyra kept starved for various periods at $9^{\circ} \mathrm{C}, 12^{\circ} \mathrm{C}$ and $15^{\circ} \mathrm{C}$. Error bars: SD. Filled triangles: $P N R_{50}$ at $15^{\circ} \mathrm{C}(33.8 \mathrm{~d}), 12^{\circ} \mathrm{C}(38.4 \mathrm{~d})$ and $9^{\circ} \mathrm{C}(58.6 \mathrm{~d})$ from left to right. Means with different letters are significantly different. 
In jellyfish respiration measurements, Purcell et al. [21] pointed out several factors influencing actual measurements, including 1) acclimation to temperature, 2) feeding conditions of specimens before experiment, 3) volume of respiration chamber, 4) acclimation and incubation times, and 5) activity of animals during experiment, although no standardized protocols have been established. In this study, A. aurita ephyrae were treated with great care before and during the respiration experiments to reduce the errors to as small as possible, and the obtained data had substantially wide variations, resulting in a relatively wide SD for each mean value. These might preclude the statistical analysis from detecting the effects of temperature and starvation duration on the respiration rates at a significant level. However, the general trends were clear: the respiration rates decreased with increasing starvation duration, and the temperature effect was not significant.

In addition, all reported respiration rates of $A$. aurita ephyrae, including those in this study, were much lower than the respiration rates of other zooplankton taxa having similar carbon contents. Assuming a carbon:dry weight ratio of 0.45 [28], the respiration rate of crustacean zooplankton, primarily copepods, from the Inland Sea of Japan [29] can be estimated as $2.55 \mu \mathrm{O}_{2}$ ind $^{-1} \mathrm{~d}^{-1}$ at $15^{\circ} \mathrm{C}$. A similar calculation can be made by interpolation of an equation derived from various zooplankton taxa from the world oceans [30], which resulted in $1.68 \mu \mathrm{l}$ $\mathrm{O}_{2}$ ind $^{-1} \mathrm{~d}^{-1}$. The extremely lower respiration rates in $A$. aurita ephyrae than in other taxa were also demonstrated when the rates were expressed in terms of dry weight-specific respiration rates (see Table A1, Figure 4). Hence, we conclude that the low metabolism rates per unit body (either dry or carbon) mass are specific to $A$. aurita ephyrae. This conclusion, however, is contradictory to results in publications by Acuña et al. [31] and Pitt et al. [32]. They have reported that the respiration rates of jellyfish are similar to those of other metazoans (e.g., crustaceans and fish) when scaled by carbon content. Interpolation to $6.6 \mu \mathrm{g} \mathrm{C} \mathrm{(carbon}$

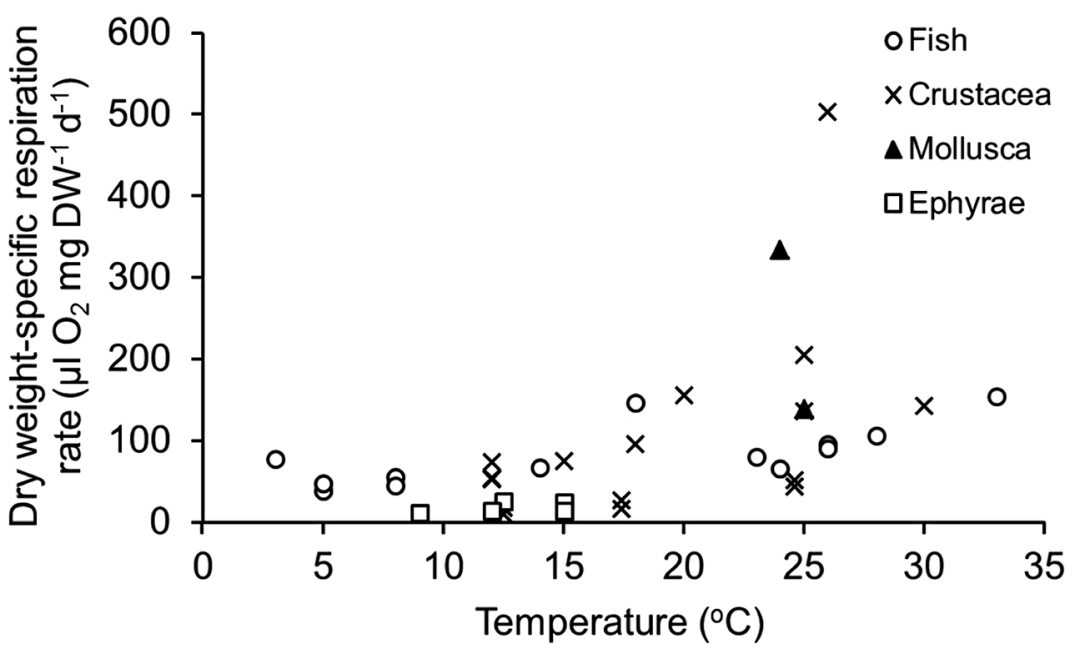

Figure 4. Dry weight-specific respiration rates of newly-hatched larvae of molluscs, crustaceans and fishes, including Aurelia aurita ephyrae. See Table A1 in the Supplementary data for dry weight-specific respiration rates of each taxon. 
weight of an A. aurita ephyra) using equations presented by Acuña et al. [31] and Pitt et al. [32] gives respiration rates of 2.9 and $2.6 \mu \mathrm{O} \mathrm{O}_{2}$ animal $^{-1} \mathrm{~d}^{-1}$, respectively, values much greater than those mentioned above for $A$. aurita ephyrae.

It is worth mentioning the differences between the measured respiration rates of newly released ephyrae (i.e., $0.24,0.24$ and $0.19 \mu \mathrm{O}_{2}$ ephyra $^{-1} \mathrm{~d}^{-1}$ at $15^{\circ} \mathrm{C}$, $12^{\circ} \mathrm{C}$ and $9^{\circ} \mathrm{C}$, respectively) and those determined indirectly from decreases in carbon content (i.e. $0.40,0.28$ and $0.27 \mu \mathrm{O}_{2}$ ephyra $^{-1} \mathrm{~d}^{-1}$ at $15^{\circ} \mathrm{C}, 12^{\circ} \mathrm{C}$ and $9^{\circ} \mathrm{C}$, respectively), which was reported by Fu et al. [9]. We suspect that the placement of ephyrae into a small volume of the DO bottles might reduce their swimming activity and thus decrease the respiration rates compared to those obtained by indirect estimation, where ephyrae were allowed to swim freely.

Since the carbon weight-specific respiration rates were stable regardless of starvation duration, the decrease in body carbon weight was responsible for reduced individual-level respiration rates for starved ephyrae. This fact also suggests that the basal metabolism was maintained at a certain fixed level for $\mathrm{A}$. aurita ephyrae so far as their metabolic substrate is available. It is noteworthy that even ephyrae starved almost to $P N R_{50}$ could maintain these metabolic kinetics.

The mean carbon weight-specific respiration rates of newly released $A$. aurita ephyrae were converted to dry weight-specific respiration rates by using a dry weight and carbon conversion factor of 0.33 (the measured value in this study) to yield $11.7,14.5$, and $14.6 \mu \mathrm{O}_{2} \mathrm{mg} \mathrm{DW}^{-1} \mathrm{~d}^{-1}$ at $9^{\circ} \mathrm{C}, 12^{\circ} \mathrm{C}$ and $15^{\circ} \mathrm{C}$, respectively, for comparison to the rates for planktonic larvae of other marine animals (i.e., molluscs, crustaceans and fish, Figure 4). The dry weight-specific respiration rates ranged from 139.2 to $333.8 \mu \mathrm{O}_{2} \mathrm{mg} \mathrm{DW}^{-1} \mathrm{~d}^{-1}$ for molluscs, from 9.6 to $504 \mu \mathrm{l} \mathrm{O}_{2} \mathrm{mg} \mathrm{DW}^{-1} \mathrm{~d}^{-1}$ for crustaceans, and from 39 to $154.1 \mu \mathrm{l} \mathrm{O} \mathrm{mg} \mathrm{DW}^{-1}$ $\mathrm{d}^{-1}$ for fish (see Table A1). Compared to these values, the rates of A. aurita ephyrae are, in general, much lower.

Based on the respiration rates, the minimum food requirement can be estimated as

$$
M F R=k \times R \times R Q / A,
$$

where $M F R$ is the minimum food requirement ( $\mu \mathrm{g} \mathrm{C} \mathrm{g}^{-1}$ ephyra $\left.{ }^{-1} \mathrm{~d}^{-1}\right), k$ is a

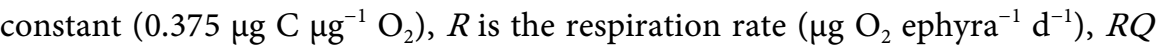
is the respiratory quotient (assumed to be 0.8 due to the protein-dominated metabolism, [33]), and $A$ is the assimilation efficiency (assumed to be $0.8,[18]$ ). The $M F R$ for a newly released ephyra was calculated to be $0.13,0.13$ and $0.10 \mu \mathrm{g}$ $\mathrm{C}$ ephyra ${ }^{-1} \mathrm{~d}^{-1}$ at $15^{\circ} \mathrm{C}, 12^{\circ} \mathrm{C}$ and $9^{\circ} \mathrm{C}$, respectively, corresponding to $2.0 \%, 2.0 \%$ and $1.6 \%$ of the ephyra carbon weight.

\subsection{Effects of Starvation and Temperature on Swimming Ability}

As $A$. aurita ephyrae are tactile predators without any ability to detect prey remotely, swimming and feeding are closely related each other. In this study, the maximum pulsation rate recorded was 49.2 beats $\mathrm{min}^{-1}$, indicating that $A$. aurita 
ephyrae are cruising predators, which swim almost continuously. If one pulsation can generate a movement of $1.8 \mathrm{~mm}$, as was observed by Sullivan et al. [34], the maximum average swimming speed of $A$. aurita ephyrae would be 8.87 $\mathrm{cm} \cdot \mathrm{min}^{-1}$. The ephyrae cannot chase prey with swimming speed higher than them, but can encounter with swimming prey. However, even in the latter case, the prey with higher swimming speeds can escape from the feeding current generated by ephyra's disc pulsation [34] and even shake off the manubrium. Therefore, $A$. aurita ephyrae are expected to capture primarily slow-moving prey, such as fish eggs, barnacle nauplii, veliger larvae and hydromedusae. Copepod nauplii (escape speed: $120 \mathrm{~cm} \cdot \mathrm{min}^{-1}$ ) and copepodites and adults (escape speed: $>300 \mathrm{~cm} \cdot \mathrm{min}^{-1}$ ) may not be the primary prey for $A$. aurita ephyrae (Figure 5).

In this study, ephyrae could actively swim at all three temperatures, and their pulsation rates did not differ significantly among the temperatures tested (an exception was for newly released ephyrae), which is contrary to the previous results. Both Mangum et al. [26] and Dillon [27] found that the pulsation rate increased with increasing temperature up to $25^{\circ} \mathrm{C}$, and then decreased with further temperature increase. A similar temperature effect was also found for A. aurita medusae [23] [24] [35]. The difference between this study and the previous ones might be attributed to longer time adaption of ephyrae to experimental temperatures in this study compared to the previous ones, where ephyrae were exposed to experimental temperatures rather suddenly. Over the temperature range at least between $9^{\circ} \mathrm{C}$ and $15^{\circ} \mathrm{C}$, where $A$. aurita ephyrae usually experience in the field, they can swim always actively to seek food and escape from predators.

It was an interesting finding that the pulsation rates of $A$. aurita ephyrae after 10 and 20 days of starvation were significantly higher than those of ephyrae of newly released. This result indicates that starvation may accelerate pulsation in order to search for more prey. The pulsation rate culminated on $20 \mathrm{~d}$ after starvation,

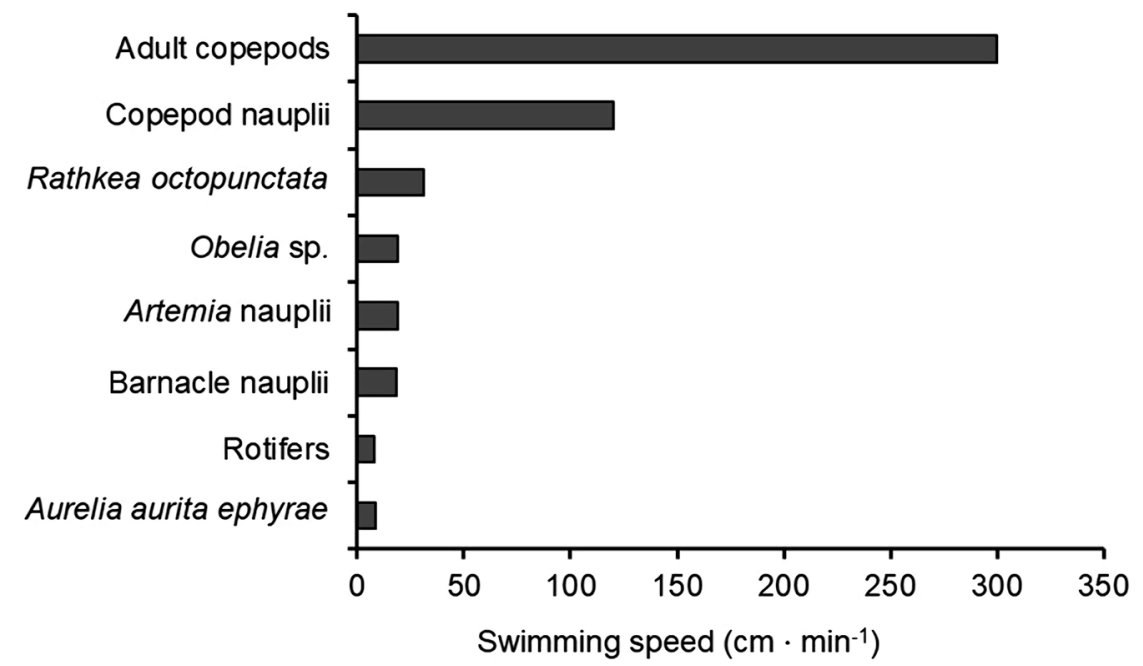

Figure 5. Comparison of the swimming speed between the Aurelia aurita ephyrae and various zooplankton. 
and thereafter the rate decreased. The decrease of pulsation rates together with body size shrinkage may significantly reduce the feeding capability of $A$. aurita ephyrae. In addition, decrease of pulsation can also cause the reduction of escaping ability from predators, leading to higher mortality of $A$. aurita ephyrae in the field.

\section{Conclusion}

The effect of starvation on respiration rates and pulsation rates of $A$. aurita ephyrae was investigated, because we considered their extremely strong starvation resistance and recovery capability may be attributed to their low metabolic rates and their swimming ability is closely associated with feeding and escaping capabilities. The respiration rate of a newly released ephyra was actually very low, i.e. $0.24,0.24$ and $0.19 \mu \mathrm{O}_{2}$ ephyra $^{-1} \mathrm{~d}^{-1}$ at $15^{\circ} \mathrm{C}, 12^{\circ} \mathrm{C}$ and $9^{\circ} \mathrm{C}$, respectively. The respiration rate tended to decrease with the increase of starvation period, but statistical analysis did not detect the effect of starvation because of wide variation of respiration rate data. The carbon weight-specific respiration rates were constant for up to the period nearly $P N R_{50}$, indicating that the kinetics for basic metabolism is stable so far as metabolic substrate is available. The minimum food requirement based on the respiration rate was equivalent to $2.0 \%, 2.0 \%$ and $1.6 \%$ of ephyra carbon weight at $15^{\circ} \mathrm{C}, 12^{\circ} \mathrm{C}$ and $9^{\circ} \mathrm{C}$, respectively. The pulsation rate was accelerated by starvation for up to $20 \mathrm{~d}$, indicating that moderately starved ephyrae actively swim so that they can capture more prey than newly released ephyrae. The maximum swimming speed achieved by $A$. aurita ephyrae was $8.87 \mathrm{~cm} \cdot \mathrm{min}^{-1}$, suggesting that their main prey is confined to slow moving zooplankton such as barnacle nauplii, veliger larvae and hydromedusae. The pulsation rate decreased for ephyrae after $30 \mathrm{~d}$ of starvation, and hence the heavily starved ephyrae may be exposed to higher predation loss.

\section{Acknowledgements}

We would like to thank the anonymous reviewers for providing constructive feedback on the manuscript. This study is partially supported by the Natural Science Foundation of Guangxi Province, China (2016GXNSFCA380015).

\section{Conflicts of Interest}

The authors declare no conflicts of interest regarding the publication of this paper.

\section{References}

[1] Dong, Z., Liu, D. and Keesing, J.K. (2010) Jellyfish Blooms in China: Dominant Species, Causes and Consequences. Marine Pollution Bulletin, 60, 954-963. https://doi.org/10.1016/j.marpolbul.2010.04.022.

[2] Dong, Z. (2019) Chapter 8: Blooms of the Moon Jellyfish Aurelia: Causes, Consequences and Controls. In: Sheppard, C., Ed., World Seas: An Environmental Evaluation, Vol. III, Ecological Issues and Environmental Impacts, Elsevier Ltd., London, 
163-171. https://doi.org/10.1016/B978-0-12-805052-1.00008-5

[3] Uye, S. (2011) Human Forcing of the Copepod-Fish-Jellyfish Triangular Trophic Relationship. Hydrobiologia, 666, 71-83. https://doi.org/10.1007/s10750-010-0208-9

[4] Purcell, J., Baxter, E. and Fuentes, V. (2013) Jellyfish as Products and Problems of Aquaculture. In: Partridge, G.J., Ed., Advances in Aquaculture Hatchery Technology, 1st Edotion, Elsevier Inc., Netherlands, 404-430.

[5] Purcell, J. and Sturdevant, M. (2001) Prey Selection and Dietary Overlap among Zooplanktivo Rous Jellyfish and Juvenile Fishes in Prince William Sound, Alaska. Marine Ecology Progress Series, 210, 67-83. https://doi.org/10.3354/meps210067

[6] Pereira, R., Teodósio, M.A. and Garrido, S. (2014) An Experimental Study of Aurelia aurita Feeding Behaviour: Inference of the Potential Predation Impact on a Temperate Estuarine Nursery Area. Estuarine, Coastal and Shelf Science, 146, 102-110. https://doi.org/10.1016/j.ecss.2014.05.026.

[7] Lynam, C.P., Gibbons, M.J., Axelsen, B.E., Sparks, C.A.J., Coetzee, J., Heywood, Benjamin, G. and Brierley, A.S. (2006) Jellyfish Overtake Fish in a Heavily Fished Ecosystem. Current Biology, 16, R492-R493.

https://doi.org/10.1016/j.cub.2006.09.012

[8] Richardson, A.J., Bakun, A., Hays, G.C. and Gibbons, M.J. (2009) The Jellyfish Joyride: Causes, Consequences and Management Responses to a More Gelatinous Future. Trends in Ecology \& Evolution, 24, 312-322.

https://doi.org/10.1016/j.tree.2009.01.010

[9] Fu, Z., Shibata, M., Makabe, R., Ikeda, H.and Uye, S. (2014) Body Size Reduction Under Starvation, and the Point of No Return, in Ephyrae of the Moon Jellyfish Aurelia aurita. Marine Ecology Progress Series, 510, 255-263. https://doi.org/10.3354/rneps10799.

[10] Ishii, H., Kojima, S. and Tanaka, Y. (2004) Survivorship and Production of Aurelia aurita Ephyrae in the Innermost Part of Tokyo Bay, Japan. Plankton Biology \& Ecology, 51, 26-35.

[11] Kinoshita, J., Hiromi, J. and Kadota, S. (1997) Do Respiratory Metabolic Rates of the Scyphomedusa Aurelia aurita Scale Isometrically Throughout Ontogeny in a Sexual Generation? Hydrobiologia, 347, 51-55. https://doi.org/10.1023/A:1002942806113

[12] Uye, S. and Shimauchi, H. (2005) Population Biomass, Feeding, Respiration and Growth Rates, and Carbon Budget of the Scyphomedusa Aurelia aurita in the Inland Sea of Japan. Journal of Plankton Research, 27, 237-248. https://doi.org/10.1093/plankt/fbh172

[13] Ishii, H. and Tanaka, F. (2006) Respiration Rates and Metabolic Demands of Aurelia aurita in Tokyo Bay with Special Reference to Large Medusae. Plankton \& Benthos Research, 1, 64-67.

[14] Moller, L.F. and Riisgard, H.U. (2007) Respiration in the Scyphozoan Jellyfish $A u$ relia aurita and Two Hydromedusae (Sarsia tubulosa and Aequorea vitrina): Effect of Size, Temperature and Growth. Marine Ecology Progress Series, 330, 149-154. https://doi.org/10.3354/meps330149

[15] Ikeda, H., Mizota, C. and Uye, S. (2017) Bioenergetic Characterization in Aurelia aurita (Cnidaria: Scyphozoa) Polyps and Application to Natural Polyp Populations. Marine Ecology Progress Series, 568, 87-100. https://doi.org/10.3354/meps12055

[16] Purcell, J.E., Bondyale-Juez, D.R., Romero-Kutzner, V., Martínez, I., Caprioli, R., Tames-Espinosa, M., Almunia, J., Alonso, E., Packard, T.T. and Gómez, M. (2019) Food Supply Effects on the Asexual Reproduction and Respiratory Metabolism of 
Aurelia aurita Polyps. Hydrobiologia, 846, 135-146.

https://doi.org/10.1007/s10750-019-04057-4

[17] Han, C.-h., Chae, J., Jin, J., Yoon, W. (2012) Estimation of the Minimum Food Requirement Using the Respiration Rate of Medusa of Aurelia aurita in Sihwa Lake. Ocean Science Journal, 47, 155-160. https://doi.org/10.1007/s12601-012-0015-5

[18] Schneider, G. (1989) Estimation of Food Demands of Aurelia aurita Medusae Populations in the Kiel Bight/Western Baltic. Ophelia, 31, 17-27. https://doi.org/10.1080/00785326.1989.10430848

[19] Gambill, M. and Peck, M.A. (2014) Respiration Rates of the Polyps of Four Jellyfish Species: Potential Thermal Triggers and Limits. Journal of Experimental Marine Biology and Ecology, 459, 17-22. https://doi.org/10.1016/j.jembe.2014.05.005

[20] Höhn, D., Lucas, C. and Thatje, S. (2017) Respiratory Response to Temperature of Three Populations of Aurelia aurita Polyps in Northern Europe. PLoS ONE, 12, e0177913. https://doi.org/10.1371/journal.pone.0177913

[21] Purcell, J., Fuentes, V., Atienza, D., Tilves, U., Astorga, D., Kawahara, M. and Hays, G. (2010) Use of Respiration Rates of Scyphozoan Jellyfish to Estimate Their Effects on the Food Web. Hydrobiologia, 645, 135-152.

https://doi.org/10.1007/s10750-010-0240-9

[22] Gemmell, B., Colin, S. and Costello, J. (2017) Widespread Utilization of Passive Energy Recapture in Swimming Medusae. Journal of Experimental Biology, 221, jeb168575. https://doi.org/10.1242/jeb.168575

[23] Hansson, L. (1997) Effect of Temperature on Growth Rate of Aurelia aurita (Cnidaria, Scyphozoan) from Gullmarsfjorden, Sweden. Marine Ecology Progress Series, $161,145-153$.

[24] Martinussen, M. and Bamstedt, U. (2001) Digestion Rate in Relation to Temperature of Two Gelatinous Planktonic Predators. Sarsia, 86, 21-35. https://doi.org/10.1080/00364827.2001.10420458

[25] Algueró-Muñiz, M., Meunier, C.L., Holst, S., Alvarez-Fernandez, S., Boersma, M. (2016) With Standing Multiple Stressors: Ephyrae of the Moon Jellyfish (Aurelia aurita, Scyphozoa) in a High-temperature, High- $\mathrm{CO}_{2}$ and Low-Oxygen Environment. Marine Biology, 163, Article No. 185.

https://doi.org/10.1007/s00227-016-2958-Z

[26] Mangum, C., Oakes, M. and Shick, J. (1972) Rate-Temperature Responses in Scyphozoan Medusae and Polyps. Marine Biology, 15, 298-303. https://doi.org/10.1007/BF00401389

[27] Dillon, T. (1972) Effects of Acute Changes in Temperature and Salinity on Pulsation Rates in Ephyrae of the Scyphozoan Aurelia aurita. Marine Biology, 42, 31-35. https://doi.org/10.1007/BF00392011

[28] Uye, S.-I. (1982) Length-Weight Relationships of Important Zooplankton from the Inland Sea of Japan. Journal of the Oceanographical Society of Japan, 38, 149-158. https://doi.org/10.1007/BF02110286

[29] Uye, S.-I. and Yashiro, M. (1988) Respiration Rates of Planktonic Crustaceans From The Inland Sea of Japan with Special Reference to the Effects of Body Weight and Temperature. Journal of the Oceanographical Society of Japan, 44, 47-51. https://doi.org/10.1007/BF02303119

[30] Ikeda, T. (1974) Nutritional Ecology of Marine Zooplankton. Memoirs of the Faculty of fisheries, Hokkaido University, 22, 91-1121.

[31] Acuña, J.L., López-Urrutia, Á. and Colin, S. (2011) Faking Giants: The Evolution of High Prey Clearance Rates in Jellyfishes. Science, 333, 1627-1629. 
https://doi.org/10.1126/science.1205134

[32] Pitt, K., Duarte, C., Lucas, C., Sutherland, K., Condon, R., Mianzan, H., Purcell, J., Robinson, K. and Uye, S.-I. (2013) Jellyfish Body Plans Provide Allometric Advantages beyond Low Carbon Content. PLoS ONE, 8, e72683.

https://doi.org/10.1371/journal.pone.0072683

[33] Ikeda, T., Torres, J.J., Hernández-León and Geiger, S.P. (2000) Metabolism. In: In: Harris, R., Wiebe, P., Lenz, J., Skjoldal, R.H. and Huntley, M., Eds., ICES Zooplankton Methodology Manual, Academic Press, San Diego, 455-532. https://doi.org/10.1016/B978-012327645-2/50011-6

[34] Sullivan, B., Suchman, C. and Costello, J. (1997) Mechanics of Prey Selection by Ephyrae of the Scyphomedusa Aurelia aurita. Marine Biology, 130, 213-222. https://doi.org/10.1007/s002270050241

[35] Olesen, N. (1995) Clearance Potential of Jellyfish Aurelia aurita, and Predation Impact on Zooplankton in a Shallow Cove. Marine Ecology Progress Series, 124, 63-72. https://doi.org/10.3354/meps124063 


\section{Appendix}

Table A1. Dry weight-specific respiration rates of newly-hatched larvae of molluscs, crustaceans and fishes, including Aurelia aurita ephyrae.

\begin{tabular}{|c|c|c|c|}
\hline Taxonomic groups and species & $\begin{array}{c}\text { Respiration rate } \\
\left(\mu \mathrm{l} \mathrm{O}_{2} \mathrm{mg} \mathrm{DW}^{-1} \mathrm{~d}^{-1}\right)\end{array}$ & Temperature $\left({ }^{\circ} \mathrm{C}\right)$ & References \\
\hline \multicolumn{4}{|l|}{ Molluscs } \\
\hline Grassostrea gigas Thunberg & 139.2 & 25 & {$[\mathrm{~A} 1]$} \\
\hline Perna perna Linnaeus & 333.8 & 24 & [A2] \\
\hline \multicolumn{4}{|l|}{ Crustaceans } \\
\hline \multirow[t]{3}{*}{ Cancer productus Randall } & 17.9 & 12.5 & [A3] \\
\hline & 17.0 & 17.4 & \\
\hline & 43.9 & 24.6 & \\
\hline \multirow[t]{3}{*}{ Carcinus meanas Linnaeus } & 73.9 & 12 & {$[\mathrm{~A} 4]$} \\
\hline & 96.0 & 18 & \\
\hline & 205.9 & 25 & \\
\hline Hyas araneus Linnaeus & 54.1 & 12 & [A5] \\
\hline H. araneus Linnaeus & 52.6 & 12 & [A6] \\
\hline H. coarctatus Leach & 53.0 & 12 & [A7] \\
\hline Farfantepenaeus paulensis Pérez-Farfante & 504.0 & 26 & [A2] \\
\hline \multirow[t]{4}{*}{ Macrobrachium holthuisi Genofre \& Lobão } & 75.6 & 15 & [A8] \\
\hline & 155.8 & 20 & \\
\hline & 136.8 & 25 & \\
\hline & 142.3 & 30 & \\
\hline \multirow[t]{3}{*}{ Panulirus interruptus Randall } & 9.6 & 12.5 & [A3] \\
\hline & 27.1 & 17.4 & \\
\hline & 52.1 & 24.6 & \\
\hline \multicolumn{4}{|l|}{ Fish } \\
\hline Anchoa mitchilli Linnaeus & 96.0 & 26 & [A9] \\
\hline \multirow[t]{4}{*}{ Chaos chanos Forsskål } & 80.1 & 23 & [A10] \\
\hline & 91.4 & 26 & [A11] \\
\hline & 107.1 & 28 & [A10] \\
\hline & 154.1 & 33 & [A10] \\
\hline \multirow[t]{2}{*}{ Clupea harengus Linnaeus } & 55.7 & 8 & {$[\mathrm{~A} 12]$} \\
\hline & 44.9 & 8 & [A13] \\
\hline Gadus morhua Linnaeus & 39.0 & 5 & [A14] \\
\hline Pleuronectes platessa Linnaeus & 47.8 & 5 & [A14] \\
\hline Sardinops caerulea Girard & 67.2 & 14 & [A15] \\
\hline Sciaenops ocellatus Linnaeus & 66.7 & 24 & [A16] \\
\hline Scomber japonicus Houttuyn & 146.4 & 18 & [A17] \\
\hline Theragra chalcogramma Pallas & 78.1 & 3 & [A18] \\
\hline
\end{tabular}




\section{Continued}

Cnidarians

Aurelia aurita ephyra

$\begin{array}{ccc}22.1-27.6 & 15 & \text { [A19] } \\ 26.4 & 10-15 & \text { [A20] } \\ 11.7 & 9 & \text { This study } \\ 14.5 & 12 & \text { This study } \\ 14.6 & 15 & \text { This study }\end{array}$

\section{Reference A}

[A1] Gerdes, D. (1983) The Pacific oyster Crassostrea gigas: Part II. Oxygen Consumption of Larvae and Adults. Aquaculture, 31, 221-231. https://doi.org/10.1016/0044-8486(83)90314-9

[A2] Lemos, D., Jorge, R.L.V. and Ngan, P. (2003) Simultaneous Measurements of Oxygen Consumption and Ammonia-N Excretion in Embryos and Larvae of Marine Invertebrates. Comparative Biochemistry and Physiology Part A: Molecular \& Integrative Physiology, 136, 321-328. https://doi.org/10.1016/S1095-6433(03)00163-6

[A3] Belman, B. and Childress, J. (1973) Oxygen Consumption of the Larvae of the Lobster Panulirus interruptus (Randall) and the Crab Cancer productus Randall. Comparative Biochemistry and Physiology Part A: Physiology, 44, 821-828. https://doi.org/10.1016/0300-9629(73)90146-1

[A4] Dawirs, R. (1983) Respiration, Energy Balance and Development during Growth and Starvation of Carcinus maenas L. larvae (Decapoda: Portunidae). Journal of Experimental Marine Biology and Ecology, 69, 105-128. https://doi.org/10.1016/0022-0981(83)90061-8

[A5] Anger, K. and Jacobi, C.C. (1985) Respiration and Growth of Hyas araneus L. Larvae (Decapoda: Majidae) from Hatching to Metamorphosis. Journal of Experimental Marine Biology and Ecology, 88, 257-270. https://doi.org/10.1016/0022-0981(85)90234-5

[A6] Anger, K. (1986) Changes of Respiration and Biomass of Spider Crab (Hyas araneus) Larvae during Starvation. Marine Biology, 90, 261-269. https://doi.org/10.1007/BF00569137

[A7] Jacobi, C.C. and Anger, K. (1985) Effect of Temperature on Respiration of Larval Stages of Hyas araneus and H. coarctatus (Decapoda, Majidae). Marine Ecology Progress Series, 26, 181-186. https://doi.org/10.3354/meps026181

[A8] Moreira, G.S., Mcnamara, J.C., Moreira, P.S. and Weinrich, M. (1980) Temperature and Salinity Effects on the Respiratory Metabolism of the First Zoeal Stage of Macrobrachium holthuisi Genofre \& Lobão (Decapoda: Palaemonidae). Journal of EXperimental Marine Biology and Ecology, 47, 141-148. https://doi.org/10.1016/0022-0981(80)90108-2

[A9] Houde, E. and Schekter, R. (1983) Oxygen Uptake and Comparative Energetics among Eggs and Larvae of Three Subtropical Fishes. Marine Biology, 72, 283-293. https://doi.org/10.1007/BF00396834

[A10] Walsh, W.A., Swanson, C. and Lee, C.S. (1991) Effects of Development, Temperature and Salinity on Metabolism in Eggs and Yolk-Sac Larvae of Milkfish, Chanos chanos (Forsskål). Journal of Fish Biology, 39, 115-125.

https://doi.org/10.1111/j.1095-8649.1991.tb04346.x

[A11] Swanson, C. (1996) Early Development of Milkfish: Effects of Salinity on Embryo- 
nic and Larval Metabolism, Yolk Absorption and Growth. Journal of Fish Biology, 48, 405-421. https://doi.org/10.1111/j.1095-8649.1996.tb01436.x

[A12] Kiøarboe, T. and Møhlenberg, F. (1987) Partitioning of Oxygen Consumption between "Maintenance" and "Growth" in Developing Herring Clupea harengus (L.) Embryos. Journal of Experimental Marine Biology and Ecology, 111, 99-108. https://doi.org/10.1016/0022-0981(87)90048-7

[A13] Holliday, F., Blaxter, J. and Lasker, R. (1964) Oxygen Uptake of Developing Eggs and Larvae of the Herring (Clupea Harengus). Journal of the Marine Biological Association of the United Kingdom, 44, 711-723. https://doi.org/10.1017/S0025315400027880

[A14] Davenport, J. and Lönning, S. (1980) Oxygen Uptake in Developing Eggs and Larvae of the Cod, Gadus morhua L. Journal of Fish Biology, 16, 249-256. https://doi.org/10.1111/j.1095-8649.1980.tb03702.x

[A15] Lasker, R. and Theilacker, G. (1962) Oxygen Consumption and Osmoregulation by Single Pacific Sardine Eggs and Larvae (Sardinops caerulea Girard). ICES Journal of Marine Science, 27, 25-33. https://doi.org/10.1093/icesjms/27.1.25

[A16] Torres, J., Brightman, R., Donnelly, J. and Harvey, J. (1996) Energetics of Larval Red Drum, Sciaenops ocellatus. Part I: Oxygen Consumption, Specific Dynamic Action, and Nitrogen Excretion. Fishery Bulletin, 94, 756-765.

[A17] Hunter, J. and Kimbrell, C. (1980) Early Life History of Pacific Mackerel, Scomber japonicus. Fishery Bulletin, 78, 89-101.

[A18] Porter, S.M. (2001) Effects of Size and Light on Respiration and Activity of Walleye Pollock (Theragra chalcogramma) Larvae. Journal of Experimental Marine Biology and Ecology, 256, 253-265. https://doi.org/10.1016/S0022-0981(00)00319-1

[A19] Moller, L.F. and Riisgard, H.U. (2007) Respiration in the Scyphozoan Jellyfish $\mathrm{Au}$ relia aurita and Two Hydromedusae (Sarsia tubulosa and Aequorea vitrina): Effect of Size, Temperature and Growth. Marine Ecology Progress Series, 330, 149-154. https://doi.org/10.3354/meps330149

[A20] Kinoshita, J., Hiromi, J. and Kadota, S. (1997) Do Respiratory Metabolic Rates of the Scyphomedusa Aurelia aurita Scale Isometrically Throughout Ontogeny in a Sexual Generation? Hydrobiologia, 347, 51-55. https://doi.org/10.1023/A:1002942806113 